\title{
English Philology Students' Opinions on their L2 Pronunciation Skills: A Changing Perspective
}

\author{
Dorota Lipińska \\ Institute of English, University of Silesia \\ e-mail:dorota.lipinska@yahoo.com
}

\begin{abstract}
The aim of this paper is to present the results of a longitudinal study based on anonymous (encoded) questionnaires filled in by a group of students enrolled at a university English Studies programme. The questionnaires analysed the students' views and opinions concerning their own pronunciation in English as an L2. The initial stage of the study took place at the beginning of the first semester of studies before the first pronunciation class in which the students took part. Then, the study participants were trained in both segmental and suprasegmental phonetics of English. Finally, they filled in almost the same questionnaire. The obtained results have shown that although initially the subjects had been satisfied with their own L2 pronunciation, later they realized that it had left a lot to be desired and it improved only after the university course in English phonetics. The participants started noticing the mistakes they had made before the course, as well as the positive improvements they experienced during and after the course. They confirmed themselves in the conviction that correct pronunciation in an L2 is vital for successful communication and that pronunciation mistakes may lead to misunderstandings and have serious consequences.
\end{abstract}

Keywords: L2 phonetics, foreign language pronunciation, pronunciation learning, pronunciation training 


\section{INTRODUCTION}

For the last few decades pronunciation studies have been in the centre of attention of numerous scholars, also in Poland, and there is a considerable number of works devoted to L2 learners' achievements in second-language pronunciation at different learning levels. Those studies comprise acquisition of L2 segments such as vowels and consonants, as well as some elements of prosody - stress or intonation, for instance (for the Polish context see e.g.: Nowacka, 2003; Porzuczek, 2002; Porzuczek, 2010; Rojczyk, 2010a; Rojczyk, 2010b; Szpyra-Kozłowska et al., 2002; Wrembel, 2002; Wysocka, 2003). A substantial amount of research has also been done in the field of teachers' and students' views and attitudes to pronunciation teaching and learning, (e.g. Lipińska, 2014; Majer, 2002; Nowacka, 2008; Sobkowiak, 2002; Szpyra-Kozłowska et al., 2002; Waniek-Klimczak, 2002; Wrembel, 2002).

However, the latter group of studies have not provided the researchers with optimistic results. They were rather disappointing and showed that both ESL/EFL teachers and learners were characterized by a low phonetic competence and that L2 classes at schools lacked the practice of correct English pronunciation. As SzpyraKozłowska (2008) noticed, the importance of phonodidactics seems to be still neglected in most Polish schools, where grammar and vocabulary are thought to be the most important aspects of language teaching/learning, and even the exams (both national and international) virtually do not include assessment of the examinees' pronunciation. Also the quality of pronunciation teaching is frequently and widely criticised by the specialists in this field (e.g. Majer, 2002; Porzuczek, 2002; SzpyraKozłowska et al., 2002; Wysocka, 2003). They noticed that teachers not only make mistakes themselves, but also use a faulty pseudo-phonetic transcription (such as $e$ sertifikejt for a certificate), cannot choose appropriate materials for a particular group of learners and often treat correcting students' current utterances as the only necessary pronunciation training.

Even though some longitudinal studies on L2 learners' production or perception of foreign speech have already been carried out (e.g. Nowacka, 2003), unfortunately, there have been no longitudinal studies focused on the learners' opinions and self-perception of their own pronunciation in an L2. However, some cross-sectional and retrospective studies can give some insight into the matter. For instance, Lipińska's (2014) study which involved high school and university students, provided some inspiring results. Even though all the groups of subjects regarded L2 pronunciation training as a crucial element of SLA/FLL, the students who had already completed a university course in English phonetics and phonology were far more critical than their younger counterparts regarding the lack of pronunciation classes at schools, their teachers' pronunciation in that language, as well as their own former pronunciation in English as an L2. They were able to name numerous features that had improved in their speech production, such as vowels, consonants or some elements of prosody. 


\section{RESEARCH METHOD}

The aim of this paper is to analyse and present the results obtained in an longitudinal study on English Philology students' opinions about their own pronunciation in ESL/EFL. The researcher wanted to examine if/to what extent the subjects' opinions would change after three semesters of L2 phonetic training at an academic level.

\subsection{Study participants}

The study participants for this research were recruited among the first-year English Philology students at the Institute of English and the Institute of English Cultures and Literatures, University of Silesia, Poland. At the beginning of the study there were 73 subjects, but eventually only 51 study participants were involved and their answers analysed, since the rest of them either resigned from studying the aforementioned programme or failed their exams and had to leave the university. There were 14 male students and 37 female students and at the beginning of the research they were about 19 years old (mean: 19.1; median: 19). They had not been formally taught English pronunciation prior to the study (potential subjects who had already studied English Philology were not accepted at the very beginning of the research). Nobody reported any hearing or speaking disorders or difficulties. They were all volunteers and were not paid for their participation in the research.

\subsection{Procedure}

The subjects were given anonymous, encoded questionnaires to fill in (special encoding allowed to compare the answers provided in two sessions by the same subjects without revealing any names or other personal data). The questionnaires contained open-ended, closed-ended and multiple choice questions. There were also statements which had to be rated with the use of 7-point Likert scale which was as follows:

\section{(Definitely true) $1-2-3-4-5-6-7$ (Not at all true).}

In the questionnaire there was also some space to provide any comments concerning the topics of the particular questions or the general idea of the questionnaire. The questionnaires were in Polish - to avoid any confusion or misunderstanding caused by the use of the learners' second language. For the purpose of this paper both the questions and the answers were translated into English.

The questionnaires were first filled in by the subjects at the beginning of the very first pronunciation class at the university that they had attended. Thus the study participants were not suggested any "correct" answers and were not biased towards phonetic training because of the contact with their teacher who was a professional phonetician. Subsequently the subjects were trained in English phonetics and phonology during the practical pronunciation classes. The course lasted 3 semesters (90 hours altogether). It consisted of both topics on segmental and suprasegmental phonetics. The students were taught such issues as vowels (monophthongs, 
diphthongs and triphthongs), consonants, weak forms, word and sentence stress, connected speech and intonation. After the whole course the study participants completed almost the same questionnaires as at the beginning of the phonetic training once again. Only a few supplementary statements were added in order to tap the differences between the students' former and current abilities concerning speaking and pronunciation skills.

\section{FINDINGS OF THE STUDY}

\subsection{Findings: Part One}

The following section presents some selected statements rated by the subjects with the use of the Likert scale, as well as a few comments provided by them below the questions and statements. Part One shows the results obtained before the pronunciation training.

The first and probably most important statement to be rated was $M y$ pronunciation in English is correct. As one can see in Figure 1, the vast majority of the study participants agreed with the statement. 49 subjects (96\%) altogether chose one of the positive answers. 33 subjects $(65 \%)$ decided that true would be the most suitable answer here. The mean result on the Likert scale equalled $=2$ (mean: 2; median: 2; standard deviation: 0.76).

Figure 1: The answers provided by the subjects at the beginning of the study; the statement My pronunciation in English is correct

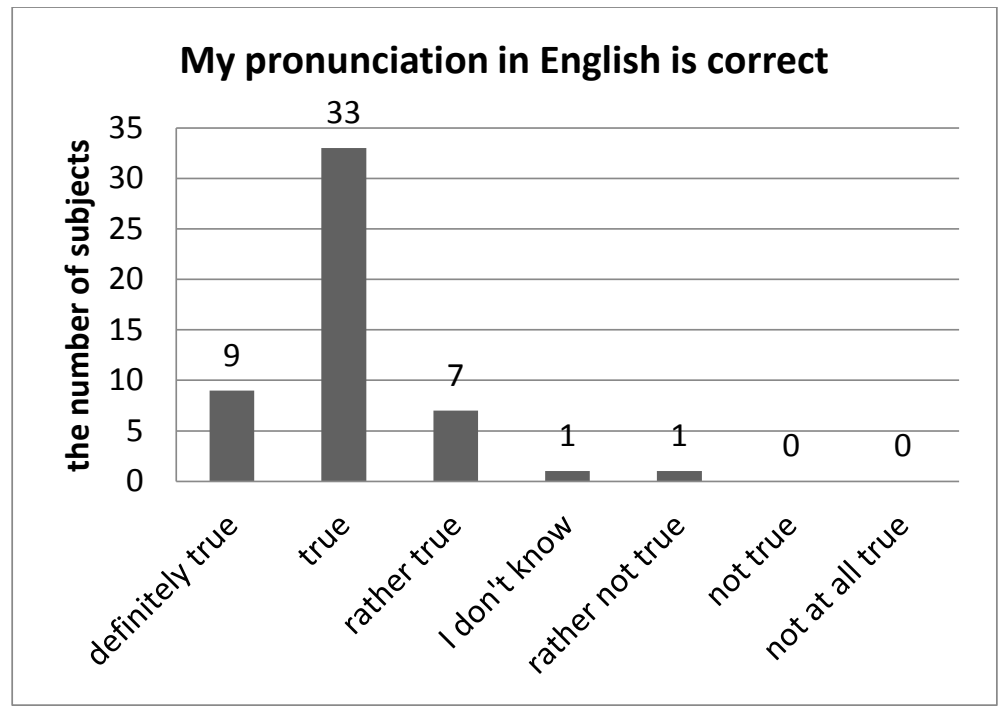

Some subjects wrote also their comments on the matter. Selected comments are presented below (they were translated from Polish by the author of the paper):

- I am fluent in English - I even passed a Cambridge FCE exam!

- I graduated from a top school in my city. My English is perfect.

- I speak English better than my friends. I don't have any communication problems. 
- Now I am a student here - it means something.

- Everybody says my English is perfect - my teachers at school were impressed.

- I speak English fluently - not like other people in Poland.

Another crucial statement was Correct pronunciation in English is crucial in successful communication. As one can see in Figure 2, here the answers were not as consistent as in the case of the previous question. Still, most subjects (35 people; $69 \%$ ) agreed with the statement, with the majority choosing the true answer (19 subjects; $37 \%$ ). The mean result on the Likert scale equalled about 3 (mean: 3.2; median: 3 ) but the standard deviation was much more significant (=1.4).

Figure 2: The answers provided by the subjects at the beginning of the study; the statement Correct pronunciation in English is crucial in successful communication

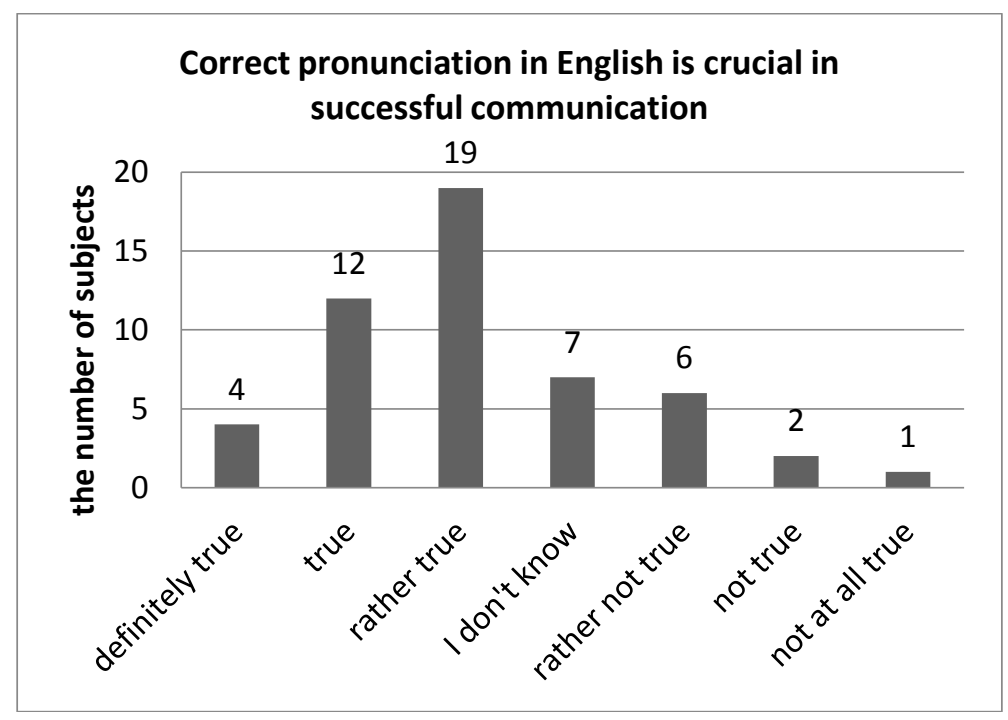

Again, here are some of the comments concerning this statement, written by the study participants and translated from Polish by the author of the paper:

- It is very important to speak correctly because a heavy foreign accent is difficult to understand.

- Correct pronunciation helps avoid misunderstandings and confusion.

- We should speak like native speakers of English.

- A foreign accent shows that someone didn't care and didn't work hard enough during English classes at school.

- I speak correctly and this is how we should do it. It's funny when I hear some foreigners speaking with heavy accents - they sound ridiculous.

- If someone has a foreign accent and posts films on You Tube in English - it's rather sad. Everybody will hate on him or her. 
Both the ratings of the statements and the comments provided by the students in this part of the study showed that in most cases they were aware of the fact that correct and intelligible pronunciation in an L2 is vital in successful communication. The subjects found a foreign accent a negative phenomenon. Moreover, they evaluated their own pronunciation in English very positively and were proud of the way they spoke.

\subsection{Findings: Part Two}

The following section presents some selected statements rated by the subjects with the use of the Likert scale, as well as a few comments provided by them below the questions and statements. Part Two shows the results obtained after the pronunciation training.

The first statement was My pronunciation in English before the phonetic training was correct. It was supposed to be compared with the first statement from Part One where the subjects evaluated their own pronunciation at the beginning of the phonetic training. As can be seen in Figure 3, the study participants' opinions concerning their own pronunciation before the practical course in English phonetics and phonology changed dramatically. They were no longer positive about it. Most subjects decided that their pronunciation in English had been incorrect. Now the mean result on the Likert scale was about 5 (mean: 5.3; median: 5; standard deviation: 1$)$.

Figure 3: The answers provided by the subjects at the end of the study; the statement My pronunciation in English before the phonetic training was correct

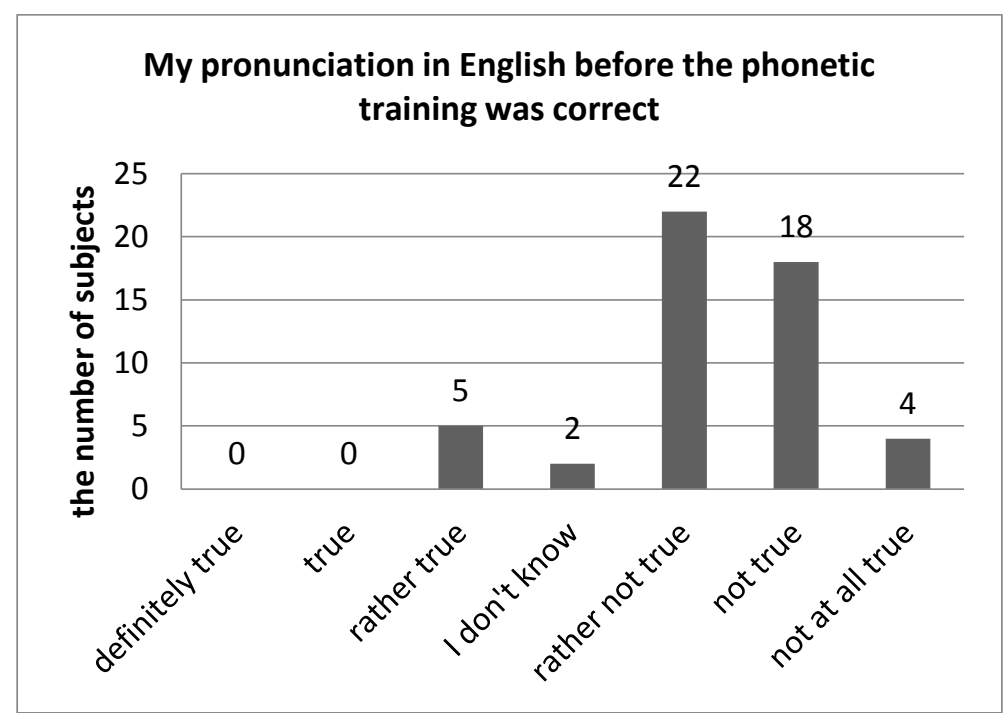

Below one can find some of the comments written by the study participants in this section (translated from Polish into English by the author of the paper): 
- Before the course at the university my pronunciation was terrible. But I wasn't aware of it.

- My pronunciation was full of mistakes. It turned out that I didn't even know how to say words like "cat" or "car". Shame.

- My pronunciation was not correct. But before the studies at our university noone had ever taught it to me!!!

- I was devastated. I had been taught incorrect pronunciation all my life. Why do teachers do it to us?! Can't they teach correct forms???

- My pronunciation teachers spoke completely differently than my teachers at school. I feel disappointed because I wasted a lot of time at school. Now, I have to learn everything once again.

- It's pathetic that teachers at schools make mistakes and teach incorrect forms.

Another statement was My pronunciation in English is now correct. As one can see in Figure 4, in this case almost all the study participants agreed. Only 6 students chose the answer I don't know and no-one decided on any disagreeing answer. The mean result on the Likert scale equalled 2.5 (median: 2; standard deviation: 0.8).

Figure 4: The answers provided by the subjects at the end of the study; the statement My pronunciation in English is now correct

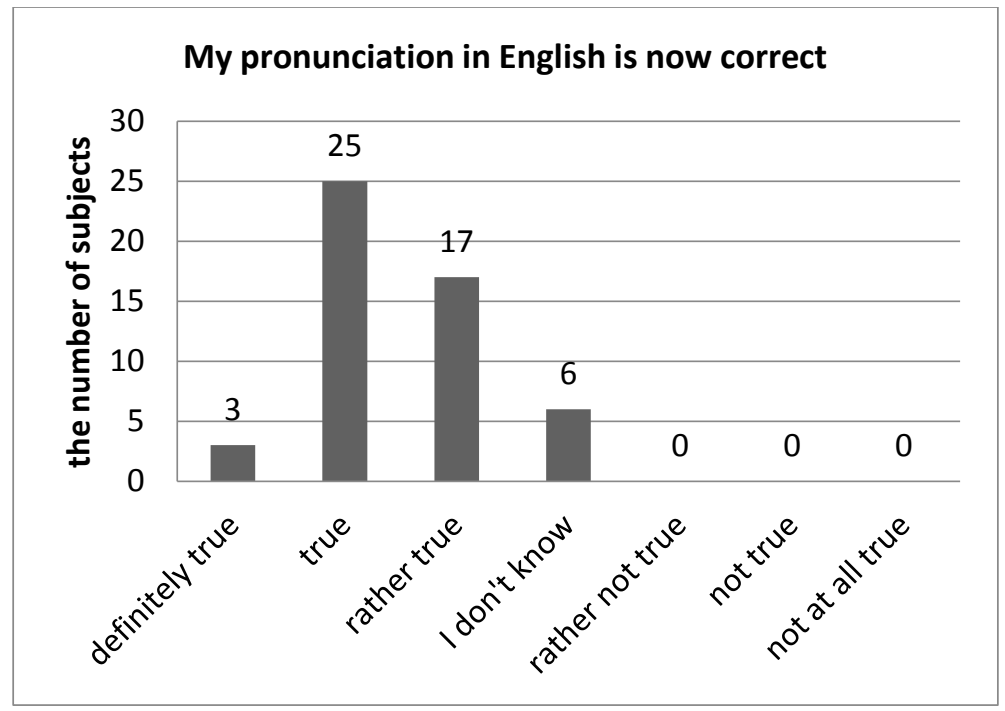

3.3 The comments on this matter provided by the subjects proved to be valuable as well. They are presented below (once again, translated from Polish into English by the author of the paper):

- I have learnt many things and I speak much better than I used to before. 
- Now I know how to speak correctly but the course in phonetics was very difficult.

- I know how to pronounce words and what intonation I should use but I can also notice mistakes made by others. My pronunciation teacher has a very nice pronunciation but other teachers and lecturers make a lot mistakes.

- It has been a long way but I'm a winner now.

- I had to learn a lot of things. I'm sure I'm much better now.

- I can speak much better now. And even if I don't know how to pronounce something, I still have my pronunciation dictionary!

The final statement described in this paper was Correct pronunciation in English is crucial in successful communication. As can be seen in Figure 5, this time the answers provided by the study participants were very consistent - actually they all agreed on it. Most of them (26 students; 51\%) chose the answer definitely true and a similar number of the subjects (22 students; $43 \%$ ) decided on true. The mean result on the Likert scale was 1.5 (median: 1; standard deviation: 0.6).

Figure 5: The answers provided by the subjects at the end of the study; the statement Correct pronunciation in English is crucial in successful communication

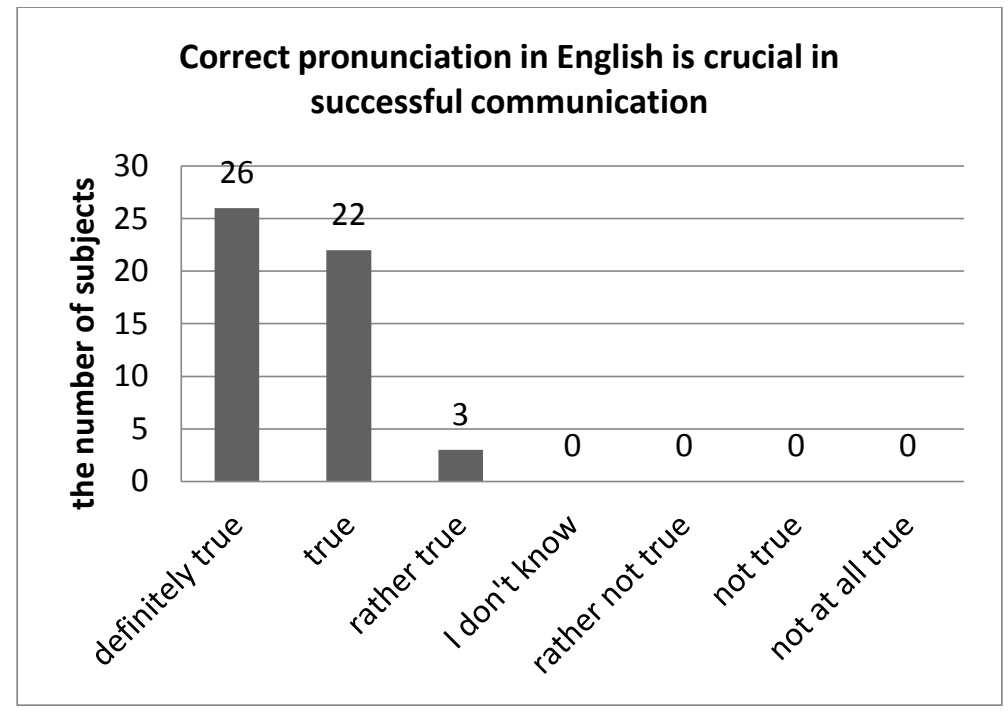

The comments written by the subjects under this statement were as follows (translated into English by the author of the paper):

- Now I know how many mistakes can be made and how it all can affect communication.

- I didn't even realise that there are so many similar words (minimal pairs)! 
- Intonation can change everything!

- We can change the meaning of the utterance if we our pronunciation is incorrect.

- I know that I can offend somebody if I use incorrect intonation-e.g. somebody may think I'm being sarcastic!

- Our teacher told us a lot of stories of pronunciation mistakes that led not only to funny situations, but also catastrophes. I remember the one about a plane that crashed. It's serious! We must speak correctly!

Both the ratings of the statements and the comments provided by the students in this part of the study showed that they changed their opinions concerning their own pronunciation in English before the university course in the practical phonetics of English. They still believed that correct pronunciation is important in successful communication, and this opinion got even stronger and was supported by some examples.

\section{CONCLUSION}

To sum up, it is worth noticing that a pronunciation course including the elements of both segmental and suprasegmental phonetics is really valuable for advanced language learners. It can make students aware of the importance of correct pronunciation in a foreign language, the significance of the pronunciation mistakes they can make and the complexity of L2 phonetic and phonological systems.

The study described in this article showed that although at the beginning of their English studies the subjects (advanced learners of English) were sure that their pronunciation in L2-English was correct, they drastically changed their minds having completed a university course in the practical phonetics and phonology of English. The study participants also started noticing the mistakes they had made before the course, as well as the positive improvements they experienced during and after the course. They confirmed themselves in the conviction that correct pronunciation in an L2 is vital for successful communication and that pronunciation mistakes may lead to misunderstandings and have serious consequences.

\section{REFERENCES}

Lipińska, D. (2014). Polish Learners' Attitudes Towards Learning English Pronunciation: Revisited. In: Majchrzak, O. (ed.) PLEJ_3 Czyli PsychoLingwistyczne Eksploracje Językowe. Łódź: Wydawnictwo Uniwersytetu Łódzkiego, pp. 129-149.

Majer, J. (2002). Sick or Seek? Pedagogical phonology in teacher training. In: Waniek-Klimczak E. \& P.J. Melia (eds.) Accents and speech in teaching English phonetics and phonology, Frankfurt am Main: Peter Lang, pp. 153176.

Nowacka, M. (2003). Analiza i ocena wymowy słuchaczy NKJO w Rzeszowie. In: Zeszyt Naukowy Instytutu Neofilologii 2. Zeszyty Naukowe PWSZ w Koninie nr 1/2003 2, pp. 46-55. 
Nowacka, M. (2008). How far is 'Hanover' from 'hangover'? Misperception of Polish ear. In: E. Waniek-Klimczak (ed.) Issues in accents of English. Newcastle: Cambridge Scholars Publishing, pp. 272-303.

Porzuczek, A. (2002). Problemy organizacji kursu fonetyki języka angielskiego. In: Sobkowiak, W. \& E. Waniek-Klimczak (eds.) Dydaktyka fonetyki języka obcego. Zeszyty Naukowe PWSZ w Płocku (2002), pp. 91-100.

Porzuczek, A. (2010). The weak forms of TO in the pronunciation of Polish learners of English. In: E. Waniek-Klimczak (ed.) Issues in accents of English 2: Variability and norm. Newcastle: Cambridge Scholars Publishing, pp. 309324.

Rojczyk, A. (2010a). Forming new vowel categories in second language speech: the case of Polish learners' production of English /I/ and /e/. Research in Language 8, pp. 85-97.

Rojczyk, A. (2010b). Production and perception of vowel /æ/ by Polish learners of English. In: K. Dziubalska-Kołaczyk, M. Wrembel, M. Kul (eds.) Proceedings from the Sixth International Symposium on the acquisition of second language speech [CD ROM version], pp. 386-391.

Sobkowiak, W. (2002). English speech in Polish eyes: What university students think about English pronunciation teaching and learning. In: WaniekKlimczak, E. \& P.J. Melia (eds.), Accents and Speech in teaching English phonetics and phonology, Frankfurt am Main: Peter Lang, pp. 177-196.

Szpyra-Kozłowska, J. (2008). English pronunciation pedagogy in Poland achievements, failures and future prospects. In: E. Waniek-Klimczak (ed.) Issues in accents of English. Newcastle: Cambridge Scholars Publishing, pp. 212-234.

Szpyra-Kozłowska, J., Frankiewicz, J. \& Gonet, W. (2002). Aspekty fonetyki angielskiej nauczane w polskich szkołach średnich. In: Sobkowiak, W. \& E. Waniek-Klimczak (eds.) Dydaktyka fonetyki języka obcego. Zeszyty Naukowe PWSZ w Płocku, pp. 9-28.

Waniek-Klimczak, E. (2002). Context for teaching English phonetics and phonology. In: Waniek-Klimczak, E. \& P.J. Melia (eds.), Accents and speech in teaching English phonetics and phonology, Frankfurt am Main: Peter Lang, pp. 139-152.

Wrembel, M. (2002). Miejsce fonetyki języka angielskiego w szkole - implikacje dla kształcenia nauczycieli. In: Sobkowiak, W. \& E. Waniek-Klimczak (eds.) Dydaktyka fonetyki języka obcego. Zeszyty Naukowe PWSZ w Płocku 2002, pp. 29-40.

Wysocka, H. (2003). Czy/jak uczyć fonetyki języka obcego? In: Zeszyt Naukowy Instytutu Neofilologii 2. Zeszyty Naukowe PWSZ $w$ Koninie nr 1/2003 .2, pp. 159-184. 